\title{
Evaluation of educational strategy, grounded on problem-based learning on nursing undergraduate
}

\author{
Avaliação da estratégia educativa fundamentada na aprendizagem baseada em problemas \\ na graduação em enfermagem
}

Miriam Fernanda Sanches Alarcon ${ }^{1}$, Kelly Holanda Prezotto ${ }^{1}$

Objective: to compare the performance of student's learning from evaluations of the method Problem-Based
Learning and the Traditional method, in a discipline of undergraduate Nursing. Methods: an experimental
study, performed with 16 students of the Degree course in Nursing. The experimental group was submitted to
the educational strategy grounded on Problem-Based Learning and the control group to Traditional education.
Cognitive Assessment Exercise evaluations were performed and traditional assessments for the two groups.
Results: students in the experimental group showed better performance when compared to students from the
traditional method. Conclusion: there was a positive influence on the strategy implemented for learning in
Nursing, such as improved of critical thinking, knowledge construction. Descriptors: Problem-Based Learning; Education, Nursing; Educational Measurement.

Objetivo: comparar o rendimento da aprendizagem dos estudantes a partir das avaliações do método Aprendizagem Baseada em Problemas e do método Tradicional em uma disciplina da graduação em Enfermagem. Métodos: estudo experimental, realizado com 16 estudantes do curso de graduação em enfermagem. 0 grupo experimental foi submetido à estratégia educativa fundamentada na Aprendizagem Baseada em Problemas e o grupo controle ao ensino Tradicional. Foram realizadas avaliações de Exercício de Avaliação Cognitiva e avaliações tradicionais para os dois grupos. Resultados: mostraram que os estudantes do grupo experimental apresentaram melhor rendimento, quando comparados aos estudantes do método tradicional. Conclusão: houve influência positiva da estratégia implementada para a aprendizagem em Enfermagem, como melhora do raciocínio crítico, construção do próprio conhecimento.

Descritores: Aprendizagem Baseada em Problemas; Educação em Enfermagem; Avaliação Educacional.

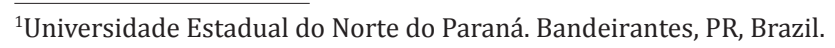




\section{Introduction}

Education through active methodologies has, as one of its proposals, to cause changes that contribute to the students growth, suggesting an active participation of the subjects in the process of knowledge, through assessment and real problem solving(1).

In this context, the traditional teaching model is gradually being replaced by new pedagogical trends, to meet the growing and demanding world of work. A critical and reflective professional is sought, able to transform the social reality of their daily lives, thus reducing the injustices and inequalities ${ }^{(2)}$.

The Problem-Based Learning is a didactic strategy where the student has an active role in education, through the discussion of real problems, looking for solutions to improve the knowledge, help in solving them, and stimulate critical thinking. Studies about the Problem-Based Learning demonstrate that its application generates improved content knowledge, in the development of education and selfdirected learning ${ }^{(3)}$.

The strategy of Problem-Based Learning has been used for various education institutions, especially in Health area courses. The University of Maastricht in the Netherlands was emphasized; Harvard and Cornell, in the United States; in Brazil, the Faculty of Medicine of Marília, the Londrina State University and São Francisco University, which successfully adopted the method ${ }^{(4)}$.

The teaching, independently the used strategy, results in the evaluation process, which varies with the used method. Tests and examinations are usually adopted for the traditional teaching, which values the ability of the student remembering what was taught and assimilated ${ }^{(5)}$.

In the strategy of Problem-Based Learning, the real problems, also denominated as paper problems, are used as a reference to promoting learning, and should include issues that address the development of professional competence and encourage basic and clinical integration and biological, psychological and social aspects ${ }^{(6)}$. The problems are formulated by a team of qualified teachers and taken to the group for the purpose of discussion.

One of the evaluations used for Problem-Based Learning is the Cognitive Assessment Exercise. It is an assessment tool of the individual ability of students to provide answers to the questions, according to the degree of complexity and autonomy of each series, taking the student to a significant learning ${ }^{(6-7)}$. In front of this, the need to conduct a study was observed, looking for evaluations analyze in different teaching methods.

Considering the importance of evaluations for the knowledge of educational strategies used in Nursing teaching, this study aimed to compare the incomes of student evaluations submitted to the Problem-Based Learning method and Traditional.

\section{Methods}

This is an experimental study that had as intervention, the method Problem-Based Learning application in the theoretical contents of the subject "Clinical Practice in High Complexity", of the Nursing degree course at the State University of Northern Parana, in the year 2012.

The research was presented at the beginning of the semester for all undergraduate students $(n=30)$ enrolled in the course, and 16 students were volunteered to participate in the study. The volunteers were divided into two groups: half were submitted to Problem-Based Learning and a half to the traditional method. The division of the groups was by a lot. The selected assigned to the first group participated in tutoring sessions in the classroom intended for Problem-Based Learning, and then designated as Experimental Group. The second group remained in 
the classroom where the discipline was held, being called Control Group.

Both groups participated in the two evaluations of the applied methods: Cognitive Assessment Exercises and Traditional Assessment, to compare the performance of students learning from the used methods.

The intervention began in the previous six months of the application of the method, where the teacher-researcher conducted the training for tutoring from February to July 2012. After, the teacherresearcher transformed the subjects of Teaching Plan on paper issues, validated subsequently by other teachers of the discipline, to ensure the validity and reliability of the study.

Previously to the application of the method, meetings were held with the team that carried out the construction of the evaluation of cognitive assessment exercise in the Health Faculty of Marília, an institution that uses Based-Learning method and cognitive assessment Exercise since 1997, with the order to discuss the construction of the evaluation in the implementation of this study.

At the first school day, when there was the presentation of the schedule, the 16 participating students signed the Consent and Informed Form. At the first week, a presentation of Problem-Based Learning for students was held, to explain the method and its steps, teaching plan, schedule of tutoring sessions and assessments that would be carried out during the semester.

The tutoring sessions were performed by a discipline teacher and consisted of the discussion of an issue that takes place in two phases. At the first, the problem is presented, and the students formulate learning objectives from the discussion, and at the second one, after the individual study performed out of the tutorial group, students re-discuss the problem.

The Problem-Based Learning was developed with eight students in another environment, different from thelocation where the control group and the other students remained, and was implemented according to the guiding principles of the methodology, over 24 classes that took place throughout the semester, containing six paper problems that reached the entire teaching plan.

The tutoring sessions performed for the experimental group happens concurrently with the traditional classes held for the other control group and students, with the same length of the traditional classes, with two weekly meetings of two hours each. Each theme comprised the opening of the issue on Tuesday, discussion on Thursday, and next Tuesday and Thursday when there was not only discussion but also the closure. The prediction, therefore, were four tutoring sessions for the development of each problem, allowing exploration of the themes proposed in programming ("Educational Plan") of that discipline.

The tutorial sessions were organized in twelve steps $^{(8)}$, shown in Figure 1.

The essential components of the discipline were not changed and assured to both students groups to the full presentation of the discipline teaching plan; including being subjected to the same evaluation criteria for other not participating students.

Data collection consisted of two evaluations of cognitive assessment exercise and two traditional assessments for each group, to evaluate the cognitive part, according to the progress schedule.

The evaluations of the conventional method were elaborated by the teachers of the studied discipline, who were already qualified for the construction of the same because they were teachers of the discipline and experience in practice its preparation. The evaluations of the cognitive assessment Exercise were prepared by the teacher who applied the Problem-Based Learning.

Both evaluations, for the two groups, were applied in the middle and end of the intervention and 
Traditional education, with grades ranging from zero through ten. The grades achieved by the participants were compared according to exploratory analysis and nonparametric statistics, compared to the median, aiming to analyze the performance of experimental and control groups, as the difference between them.

The survey data were organized in tables. To compare the scores obtained by using two evaluation systems within a group and between the based learning problems and Traditional groups, using the Mann-Whitney test. Microsoft Excel programs and R 2.15.3 software were used, considering a significance level of $5 \%$.

The evaluations were corrected without the researcher corrector knew who was the student, or the method which the student was being submitted.

The study complied with the formal requirements contained in the national and international standards of regulatory research involving human subjects.

\begin{tabular}{|c|c|}
\hline 1 & $\begin{array}{l}\text { To explain the given problem, exploring it and reflecting on the existing possibility of any questions that may be made about the } \\
\text { description of the problem. }\end{array}$ \\
\hline 2 & Summary of the data provided by the problem, specifying: What is the problem? What is the problem issue? \\
\hline 3 & $\begin{array}{l}\text { Identification of areas/important points about the problem by defining the relevant areas of knowledge from the three perspectives: } \\
\text { biological, psychological and population, and considering the learning objectives for each educational unit. }\end{array}$ \\
\hline 4 & $\begin{array}{l}\text { Identification of current knowledge about the problem, through the search for relevant knowledge forward to the proposed } \\
\text { learning objectives. }\end{array}$ \\
\hline 5 & Development of hypotheses from the explanation of the data presented in the problem. \\
\hline 6 & $\begin{array}{l}\text { Identification of additional knowledge required to improve the understanding of the problem, based on the needs of individual } \\
\text { and/or group learning. }\end{array}$ \\
\hline 7 & $\begin{array}{l}\text { Identification of appropriate learning resources, among other matters: books, newspapers (magazines); local databases (Medline, } \\
\text { Lilacs) or remote (Internet, Bireme); interactive multimedia programs; interviews with teachers, professionals or users; videos; } \\
\text { slides; laboratories; health and community services; i.e. (in other words), which are the sources of most appropriate resources to } \\
\text { exploitation of this issue? }\end{array}$ \\
\hline 8 & $\begin{array}{l}\text { Search for new knowledge, using appropriate learning resources; which implies expanding the search horizons beyond institutional } \\
\text { boundaries (other libraries, other collections, other locations that may be used in the active process of teaching and learning). }\end{array}$ \\
\hline 9 & $\begin{array}{l}\text { Summary of previous and new knowledge about the problem; that is, based on solid scientific evidence: how can the be explained } \\
\text { problem now? }\end{array}$ \\
\hline 10 & Repeating some or all of the above steps, if necessary. \\
\hline 11 & Recognition of what has been identified as a learning need, but that was not adequately exploited to further incursions. \\
\hline 12 & $\begin{array}{l}\text { Summary of knowledge earned and, if possible, to test the understanding of the knowledge acquired during their application in } \\
\text { another situation or problem. }\end{array}$ \\
\hline
\end{tabular}

Figure 1 - Steps for problem-based learning implementation 


\section{Results}

The study included 16 students who were divided into two groups. Eight participated in the intervention of Problem-Based Learning (experimental group), and others attended the course with the traditional method (control group). The age of the experimental group ranged from 19 to 21 years old, six female and two male. In the control group, the age was observed between 19 and 35 years old, seven females and one male.

Table 1 and 2 shows a comparison of the performance of evaluations (cognitive and traditional evaluation exercise in experimental and control groups).

Table 1 - Performance comparison between the Experimental and Control groups in evaluations of cognitive assessments Exercise

\begin{tabular}{lcccc}
\hline \multirow{2}{*}{ Groups } & \multicolumn{2}{c}{$\mathbf{1}^{\text {st }}$ Evaluation } & \multicolumn{2}{c}{$\mathbf{2}^{\text {nd }}$ Evaluation } \\
\cline { 2 - 5 } & Median & SD & Median & SD \\
\hline Experimental & 8.6 & 0.76 & 7.4 & 1.83 \\
Control & 7.0 & 2.10 & 5.9 & 2.06 \\
P-value & 0.140 & \multicolumn{3}{c}{0.194} \\
*Grades variation: from zero to ten; SD: standard deviation
\end{tabular}

Table 2 - Yield comparison between Experimental and Control groups in the $1^{\text {st }}$ and $2^{\text {nd }}$ Traditional assessment

\begin{tabular}{lccccc}
\hline \multirow{2}{*}{ Groups } & \multicolumn{2}{c}{$\mathbf{1}^{\text {st }}$ Evaluation } & \multicolumn{2}{c}{$\mathbf{2}^{\text {nd }}$ Evaluation } \\
\cline { 2 - 3 } \cline { 5 - 6 } Median & SD & & Median & SD \\
\cline { 3 - 5 } Experimental & 6.2 & 0.96 & & 8.4 & 0.58 \\
Control & 5.5 & 0.88 & 7.4 & 1.04 \\
p-value & 0.527 & & 0.278 \\
*Grades variation: from zero to ten; SD: standard deviation
\end{tabular}

The grades of the first assessments (Exercise of cognitive and traditional evaluation) in the experimental group were higher than in the control group (Table 1 and 2). A similar incident occurred in the second evaluation. However, there was no statistical difference between the groups.

Table 3 and 04 shows a comparative yield of evaluations (cognitive and traditional evaluation exercise) experimental and control intra-groups.

Table 3 - Intra-group comparison of the grades obtained by the Experimental and Control group in the $1^{\text {st }}$ assessment of the exercise of cognitive and traditional assessment

\begin{tabular}{lccccc}
\hline \multirow{2}{*}{ Evaluation } & \multicolumn{2}{c}{ Experimental } & \multicolumn{2}{c}{ Control } \\
\cline { 2 - 3 } & Median & SD & & Median & SD \\
\hline Cognitive assessment exercise & 8.6 & 0.76 & 7.0 & 2.10 \\
Traditional & 6.2 & 0.96 & 5.5 & 0.88 \\
p-value & 0.020 & \multicolumn{3}{c}{0.226} \\
*Grades variation: from zero to ten; SD: standard deviation
\end{tabular}

Table 4 - Intra-group comparison of the grades obtained by the Experimental and Control group in the $2^{\text {nd }}$ evaluation of the cognitive and traditional exercise assessment

\begin{tabular}{lccccc}
\hline \multirow{2}{*}{ Evaluation } & \multicolumn{2}{c}{ Experimental } & \multicolumn{2}{c}{ Control } \\
\cline { 2 - 3 } \cline { 5 - 6 } & Median & SD & & Median & SD \\
\hline Cognitive assessment exercise & Median & SD & Median & SD \\
Traditional & 8.4 & 0.58 & 7.4 & 1.04 \\
p-value & 0.278 & & 0.160 & \\
*Variação das notas: zero à dez. DP: desvio padrão &
\end{tabular}

The application of the results of the first assessments, Traditional and cognitive assessment Exercise, in the Experimental group, showed that the median values of the grades to these assessments presented statistically significant differences (Table $3)$.

For the second evaluation, there was no significant difference between the median of the $2^{\text {nd }}$ evaluation of cognitive assessment exercise and the $2^{\text {nd }}$ Traditional assessment, both for the experimental group as for the control group (Table 4).

It is noted that the cognitive assessment exercise evaluation, have higher grades than the traditional evaluation in the experimental group. However, this difference was not observed in the control group, i.e., both evaluations obtained "similar" behavior values in 
this first evaluation. As for the $2^{\text {nd }}$ evaluation, grades behavior is randomly related to the groups.

\section{Discussion}

Learning active methods have been identified as effective tools for the teaching process. The Problem-Based Learning is shown as a teaching strategy in which the student has an active role in learning, seeking solutions to improve the knowledge and critical thinking ${ }^{(3)}$. This research showed the yield of traditional evaluations and exercise of cognitive assessment of students who underwent the intervention of Problem-Based Learning and students of Traditional method, in a discipline of the undergraduate degree in Nursing, to improve the implementation of the method.

The small sample size and the lack of time for research are emphasized as the main limitations because the discipline was held concurrent with the other semester. It is important to emphasize, although there are multiple types of assessments as modular, progressive, skills and informal and can be used to evaluate teaching methods.

However, the use of evaluation grades of an active methodology can lead students to rethink their responses, which become the source of reflection and learning, to recognize their progress and difficulties in the teaching-learning process, and rebuilding knowledge every day.

Another limitation was the lack of local and suitable furniture for performing the method, such as computers, multimedia kit, Data show, internet access, round table, blackboard, the difficulty in finding references in the library, which has relatively small amount of sources for research, and curricular structure that keeps many disciplines, factors that hindered the intervention study.

The application of Problem-Based Learning method requires an extensive library with books in sufficient numbers ${ }^{(9)}$. In the active methodology, a library with updated collection is needed, that seeks to develop skills and human interaction ${ }^{(10)}$, so adaptations were necessary for the application of the method about the literature sources as book loans from teachers to students.

It is important to note that students in the experimental group were used to a passive learning, linked to the traditional method, and difficulties arose from the proposed learning strategy. By appropriating the dynamic proposal, they ceased to be passive recipients and began to look for the best way of learning because, in the traditional method, the student is inhibited to participate together with others because the demonstration is not required, so the student can accommodate and let the time pass.

Despite the mentioned limiting factors, the Problem-Based Learning method was relevant in the context of education of universities, to encourage students to actively participate in their learning. Research conducted in São Paulo showed that students evaluated the Problem-Based Learning positively, and preferred this to conventional methods ${ }^{(11)}$.

For any teaching method, it is necessary to evaluate the student's learning, once to identify the level of knowledge; one can modify the teaching methodology. The act of evaluating helps the teacher to identify whether the goals are being met, given the intervention of the teacher to improve the results. And for the teacher can act focused on best strategies, it is necessary to develop the student as a being in motion, training, and act coherently from this conception ${ }^{(12)}$.

The evaluations have different characteristics, and in the Traditional method, the evaluation function is to know how much knowledge the student has accumulated. On the other hand, the Cognitive Assessment Exercise provides greater student participation in the evaluation process through cases of lived practice. The issues analyzed in the evaluations of cognitive assessment Exercise of the Problem-Based Learning group, possessed the focus to investigate whether the knowledge of students reached the goal expected by discipline, to contemplate the teaching plan proposed by the discipline. 
Concerning the results of this study, there was no statistical difference between the groups for the evaluation of Problem-Based Learning and Traditional methods. Study of educational strategy application about Nursing Diagnoses grounded on the Problem-Based Learning, conducted with 30 students at a public university, divided into control and experimental group, compared the average grades of students, finding no statistically significant difference between the experimental and control group ${ }^{(13)}$.

A survey conducted by pre-test and post-test with experimental and control groups, demonstrated the contribution of Problem-Based Learning in the clinical reasoning of students, through data analysis, the students in the experimental group identified a higher number of nursing diagnoses and related factors, improvement in data grouping ability and judgment of diagnoses ${ }^{(13)}$.

In this study, the experimental group had higher yield in all evaluations, Cognitive Assessment Exercise and Traditional, compared with the control group. This fact can be explained by the stimulus and motivation that the practice of Traditional of differentiated education provides. The use of Problem-Based Learning makes the student seek knowledge and therefore, has a greater dedication to study objects. The student assumes an active role in their learning, where the real-life problems are discussed, seeking to solve them and encouraging critical thinking ${ }^{(3)}$.

In the mentioned method, the learning process is based on everyday problems, directing the studies to generate questions that will be discussed and resolved by the group, expanding their experiences ${ }^{(14)}$.

Considering only the students in the experimental group, it was observed a better performance in the first evaluation of the Cognitive Assessment Exercise about traditional evaluation. On the other hand, in the second time, the group got better grades in the traditional evaluation. This frame was concurrently observed in the control group.

The best yield of Cognitive Assessment Exercise at first, for both groups, can be explained by the motivation of a new applied evaluation method, and also being the beginning of the school year. With the passage of time, may have been reducing the time dedicated to the innovative method and the accumulation of disciplines with the traditional method that went along with the discipline which was applied to Problem-Based Learning may have contributed to the reduction in the use of cognitive assessment Exercise.

The best performance in the second Traditional evaluation, in both groups, refers to the fact that this practice is part of their daily lives, since the beginning of school life. Thus, the evaluation habit built over time may have influenced the final result. However, the traditional teaching has obstacles to the practice of completeness, necessary for Nursing learning and new pedagogical practices become effective for the critical work of the students in their training(15).

\section{Conclusion}

The results of this research, obtained through the evaluations of the Problem-Based Learning and Traditional method, showed that the yield of the first strategy approach was effective, with better results in the Nursing course discipline.

There was a statistically of no difference between the groups in the Cognitive Assessment Exercise and Traditional evaluations, however, when analyzing the grades within the groups, in the $1^{\text {st }}$ evaluation of the experimental group was verified a significant difference between the Cognitive Assessment Exercise and Traditional evaluation, and this first compared to the students groups, obtained higher yields in the first type of assessment.

This application experience of a new educational strategy in the Nursing graduate course can contribute to the improvement of the teachinglearning process, indicating to the educational institution, teachers and students, that can occur a transformation in education.

However, to achieve this, we must rely on the 
proposed objectives and join forces because only with the cooperation and effort of all it would be possible to improve education in Nursing courses and assist in the formation of critical and reflective professionals who seek the transformation of social reality and effective action on the health needs of the population.

We suggest further research with larger numbers of participants to the traditional reviews and Cognitive Assessment Exercise, and other types of assessments to analyze the methods.

\section{Collaborations}

Alarcon MFS contributed to design, project elaboration, analysis and data interpretation. Prezotto $\mathrm{KH}$ contributed to the writing of the article, relevant critical review and final approval of the version to be published.

\section{References}

1. Carraro TE, Prado ML, Silva DGV, Radunz V, Kempfer SS, Sebold LF. Socialização como processo dinâmico de aprendizagem na enfermagem: uma proposta na metodologia ativa. Invest Educ Enferm. 2011; 29(2):248-54.

2. Prado ML, Velho MB, Espíndola DS, Sobrinho SH, Backes VMS. Arco de Charles Maguerez: refletindo estratégias de metodologia ativa na formação de profissionais de saúde. Esc Anna Nery. 2012; 16(1):172-7.

3. Staun M, Bergstrom B, Wadensten B. Evaluation of a PBL strategy in clinical supervision of nursing students: Patient- centred training in studentdedicated treatment rooms. Nurse Educ Today. 2010; 30(7):631-7.

4. Ribeiro VMB, Ribeiro AMB. A aula e a sala de aula: um espaço- tempo de produção de conhecimento. Rev Col Bras Cir. 2011; 38(1):71-6.

5. Pereira DR, Flores MA. Percepções dos estudantes universitários sobre a avaliação das aprendizagens: um estudo exploratório. Avaliação (Campinas). 2012; 17(2):529-56.
6. Faculdade de Medicina de Marília. Caderno de avaliação: cursos de medicina e enfermagem. Marília: Faculdade de Medicina; 2015.

7. Melo MC, Queluci GC, Gouvêa MV. Problematizing the multidisciplinary residency in oncology: a practical teaching protocol from the perspective of nurse residents. Rev Esc Enferm USP. 2014; 48(4):706-14.

8. Komatsu RS. Aprendizagem baseada em problemas: sensibilizando o olhar para o idoso. Londrina: Rede Unida; 2003.

9. Borges MC, Chachá SGF, Quintana SM, Freitas LCC, Rodrigues MLV. Aprendizagem baseada em problemas. Medicina. 2014; 47(3):301-7.

10. Campos CJG, Sobral FR. Problematization strategy: experience report in the care process course in psyquiatric nursing. Rev Rene. 2013; 14(5):10419.

11. Santana CA, Cunha NL, Soares AKA. Avaliação discente sobre a metodologia de ensino baseado em problemas na disciplina de Farmacologia. Rev Bras Farm. 2012; 93(3):337-40.

12. Gomes AP, Arcuri MB, Cristel ETC, Ribeiro RM, Souza LMBM, Siqueira-Batista R. Avaliação no ensino médico: o papel do portfólio nos currículos baseados em metodologias ativas. Rev Bras Educ Med. 2010; 34(3):390-6.

13. Lira ALBC, Lopes MVO. Nursing diagnosis: educational strategy based on problem-based learning. Rev Latino-Am Enfermagem. 2011; 19(4):936-43.

14. Mezzari A. The use of Problem-Based Learning (PBL) as reinforcement for students using the moodle learning environment. Rev Bras Educ Méd. 2011; 35(1):114-21.

15. Machado MLP, Oliveira DLLC, Manica ST. Consulta de enfermagem ampliada: possibilidades de formação para a prática da integralidade em saúde. Rev Gaúcha Enferm. 2013; 34(4):53-60. 